\title{
Benthic foraminifera and environmental changes in the Quaternary of the western Mediterranean coast: the core of Xeraco, Valencia, Spain
}

\author{
Juan USERA*, Jordi GUILLEM, Carmen ALBEROLA \& Ignacio GARCÍA
}

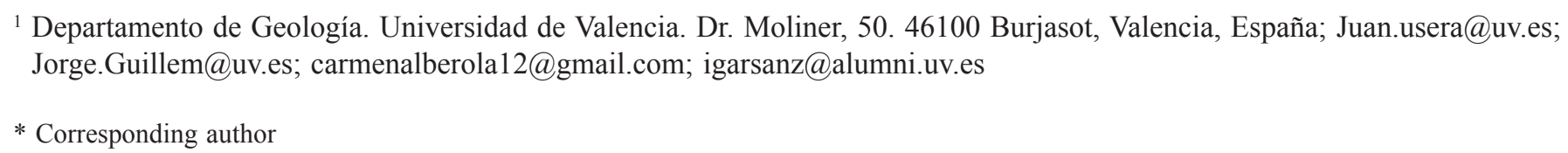

Usera, J., Guillem, J., Alberola, C. \& García, I. 2017. Benthic foraminifera and environmental changes in the Quaternary of the western Mediterranean coast: the core of Xeraco, Valencia, Spain. [Foraminíferos bentónicos y cambios ambientales en el Cuaternario de la costa occidental mediterránea: el sondeo de Xeraco, Valencia, España]. Spanish Journal of Palaeontology, 32 (1), 79-94.

\begin{abstract}
The evolution of the benthic foraminiferal assemblages from a $60 \mathrm{~m}$ core drilled in the Quaternary lagoon of Xeraco (Valencia, Spain) is studied. Two moments of warm climate, high sea-level and maximal marine influence in the lagoon have been identified. The first one at the base of the core, punctuated by highly frequent changes during the Upper Pleistocene, and the other one in the upper end of the series during the Holocene. The presence of a middle core section with low diversity and a nearly total absence of marine foraminifers is interpreted as a regressive interval of cold climate conditions linked to a glacial stage.
\end{abstract}

Keywords: Foraminifera, Quaternary, palaeoenvironments, Xeraco, Valencia.

\begin{abstract}
RESUMEN
Se estudia la evolución temporal de las asociaciones de foraminíferos bentónicos obtenidas de las muestras de un sondeo de $60 \mathrm{~m}$ de longitud realizado en la laguna costera cuaternaria de Xeraco (Valencia, España). Los cambios en estas asociaciones han permitido identificar dos momentos de máxima influencia marina, clima cálido y nivel del mar elevado. El primero de ellos en la base del sondeo y con presencia de cambios frecuentes en cuanto a esta influencia durante el Pleistoceno Superior, y otro superior con máxima influencia marina durante el Holoceno. La presencia de un tramo intermedio en que las especies de foraminíferos marinos están prácticamente ausentes, se identifica como una época de retroceso del nivel del mar, ligada a un enfriamiento global por glaciarismo.
\end{abstract}

Palabras clave: Foraminiferos, Cuaternario, paleoambientes, Xeraco, Valencia. 


\section{INTRODUCTION}

Although the Lower Pleistocene is poorly represented in the Valencian Community (some deposits possibly belonging to this epoch have been preserved in cliff sections, see Fumanal, 1995), the Middle Pleistocene (Marine Isotopic Stages 9 to 6) has been found in tectonically stable areas, such as in Xàbia (Usera et al., 1990a; Fumanal et al., 1991, 1993; Usera \& Mateu, 1995; García-Forner, 1997) or Oliva-Pego (Viñals, 1996; García-Forner, 1997; Torres et al., 2014), where the stratigraphic record of the subsurface deposits shows two marine positive pulses alternating with continental sedimentation. The Upper Pleistocene (Marine Isotopic Stages MIS-5 to MIS-2) is easily identified in all the coastal sectors in Xàbia (Fumanal et al., 1993; Viñals et al., 1993; García-Forner, 1997), Pego (Dupré et al., 1988; Mateu, 1989; Viñals et al., 1989; García-Forner, 1997) and Elx (Blázquez, 2005; Blázquez \& Usera, 2010). The Eemian interglacial corresponds to a high sea level whose deposits are preserved in littoral facies in low coasts and in dunes located next to the cliffs (Fumanal, 1995). Marine Isotopic Stages (MIS) 4, 3 and 2 are generally regressive with predominating continental, swamp or eolian facies, with some positive pulses (Martrat et al., 2004).

The current littoral is established during the Holocene. The Flandrian maximum in the Valencian coast took place around 6000 years BP, when the sea invaded a previously emerged continental surface. Some relict beaches have been identified in areas where the coastline was located several kilometres inland from its current position, such as the Oliva-Pego marsh. In other cases, like in Moraira, Xàbia or Peníscola, the inland advance of the coastline seems to have been less important (Fumanal \& Viñals, 1989; Viñals \& Fumanal, 1990, 1991; Fumanal et al., 1991).

Finally, the bars that close the current coastal lagoons formed in the upper Holocene. In some cases they can be found next to the Pleistocene ones as in Peníscola (Usera et al., 2006), Torreblanca (Usera et al., 1996a), Benicàssim (Usera et al., 1996b), l'Albufera de València (Sanjaume, 1985; Usera et al., 1990b; Sanjaume \& Carmona, 1995; Rosselló, 1995; Santisteban et al., 2009; Marco-Barba et al., 2013; Carmona et al., 2016), l'Albufereta d'Alacant (Blázquez \& Ferrer, 2012; Ferrer \& Blázquez, 2012) and Elx (Blázquez, 2005; Blázquez \& Usera, 2010).

These processes have also been identified in other areas of the Mediterranean such as the Asperillo and BarbateMeca cliffs and the estuaries of the rivers Guadalete, TintoOdiel, Guadalquivir and Guadiana in the Gulf of Cadiz, several rambla deposits in the Alboran coast or the beachbarrier systems of Roquetas in Almería province or Doñana in the Gulf of Cadiz (Goy et al., 2003; Zazo et al., 2008).

This work focuses on one of these littoral lagoons, the Quaternary albufera of Xeraco, which has already been analysed in some preliminary studies (García-Blázquez et al., 2008; Usera et al., 2012). Our goal is the reconstruction of the environmental evolution in this location of the Mediterranean coast basing on the study of its fossil foraminiferal assemblages. This comprises the information provided by both the different species about their habitats and several statistical indices about species richness and diversity and assemblage complexity.

\section{MATERIAL AND METHODS}

The studied material was recovered from a borehole drilled in the locality of Xeraco (Valencia, Spain) (Fig. 1), in the site known as Els Borrans, on one of the still remaining Pleistocene bars. Its precise geographical location is: $39^{\circ}$ 02 ' $53^{\prime \prime} \mathrm{N}$ and $00^{\circ} 11^{\prime} 06^{\prime \prime} \mathrm{W}$.

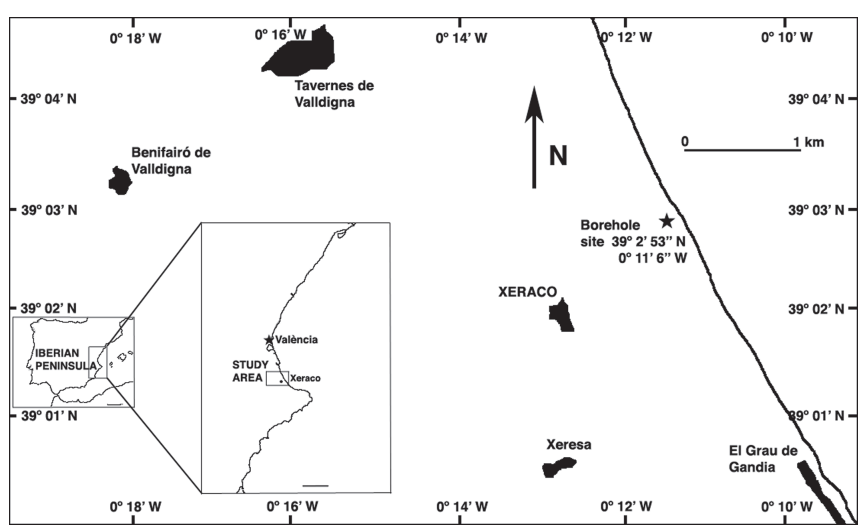

Figure 1. Geographical location of the Xeraco borehole (simplified from García-Blázquez et al., 2008).

The studied core was extracted by a rotary drilling procedure that produced a cylindrical section of sedimentary material with a $15 \mathrm{~cm}$ diameter. Sediments were recovered by introducing $3-\mathrm{m}$-long cylinders with a toothed drilling head at their end. Subsequently the corresponding 3-m-long cylindrical sections of sediments were extracted by hydraulic pressure, placed in specific boxes and transported to the laboratory to be prepared and studied.

In order to avoid any eventual contamination during the core extraction the external $1 \mathrm{~cm}$ of each sample surface was discarded. Samples for micropalaeontological analysis were taken from the core every $10 \mathrm{~cm}$ in some sections in order to obtain as much precise information as possible about even short duration environmental changes occurring in the basin. A total of 205 samples, each one with an initial weight of about $50 \mathrm{~g}$ before the laboratory preparation phase, were analysed.

Samples were dried and then disaggregated in 40-50 ${ }^{\circ} \mathrm{C}$ water. This non-aggressive technique intends to prevent 
the destruction of foraminiferal agglutinated tests with an organic lining. The sediment was wet sieved through a $0.063 \mathrm{~mm}$ mesh that prevents the loss of small-sized species, typical of restricted environments, and juveniles. Samples were then dried, split into fractions using a splitter and, when possible, at least 300 foraminiferal tests per sample (or otherwise all available tests) were picked, classified under a binocular microscope, fixed to micropalaeontological slides and counted. Although 100 tests can be generally considered as the minimum sample size for further statistical analyses (Fatela \& Taborda, 2002), we decided to include here also the nine samples containing 50-100 tests, since all contained few species and in most of them (with only one exception) more than $50 \%$ of the total sample was represented by a single taxon (Patterson \& Fishbein, 1989). This inclusion did not alter the results or the conclusions in any significant way.

The use of different diversity indices is relatively frequent in environmental studies of benthic foraminifera (Murray, 1973, 1991, 2006). Besides the simple species richness (number of species in each sample), four additional diversity indices, based on different characteristics (Magurran, 1989), were employed here to characterise the diversity of the benthic foraminiferal assemblages and to track environmental changes along the stratigraphic sequence. Two of the measures, the Fisher $\alpha$ index (Fisher et al., 1943) and the Margalef richness index (Margalef, 1958), depend on both the number of species and the number of tests in the sample. The Fisher $\alpha$ index has been widely used in foraminiferal ecological studies but its determination requires the use of specific software or graphical plots and tables (e.g. Hayek \& Buzas, 1997). In contrast, the Margalef index has been less employed but can be very easily calculated. On the other side, the Pielou's equitability or evenness J' index (Pielou, 1969) specifically reflects the distribution of tests among taxa and depends on the Shannon-Wiener H' heterogeneity index (Shannon \& Weaver, 1949), which also takes into account the number of species and has been very frequently used too in foraminiferal studies (the formula with the natural logarithm was employed here).

Three environmental groups of benthic foraminifera (lagoonal, transitional and strictly marine), together with their predominant species and their relative abundance variations were considered. In addition, the proportion of dextral and sinistral-coiling forms of the largely abundant species Ammonia beccarii was calculated for every sample with more than 50 specimens of this species in order to check any eventual link to environmental changes (Longinelli \& Tongiorgi, 1964).

Available radiocarbon $\left({ }^{14} \mathrm{C}\right)$ datings published previously by García Blázquez et al. (2008) yielded Upper Pleistocene ages for three levels at $28.70 \mathrm{~m}, 18.50 \mathrm{~m}$ and $16.50 \mathrm{~m}$ core depth and Holocene ages for five additional levels between $13.90 \mathrm{~m}$ and $3 \mathrm{~m}$ core depth (Fig. 2).

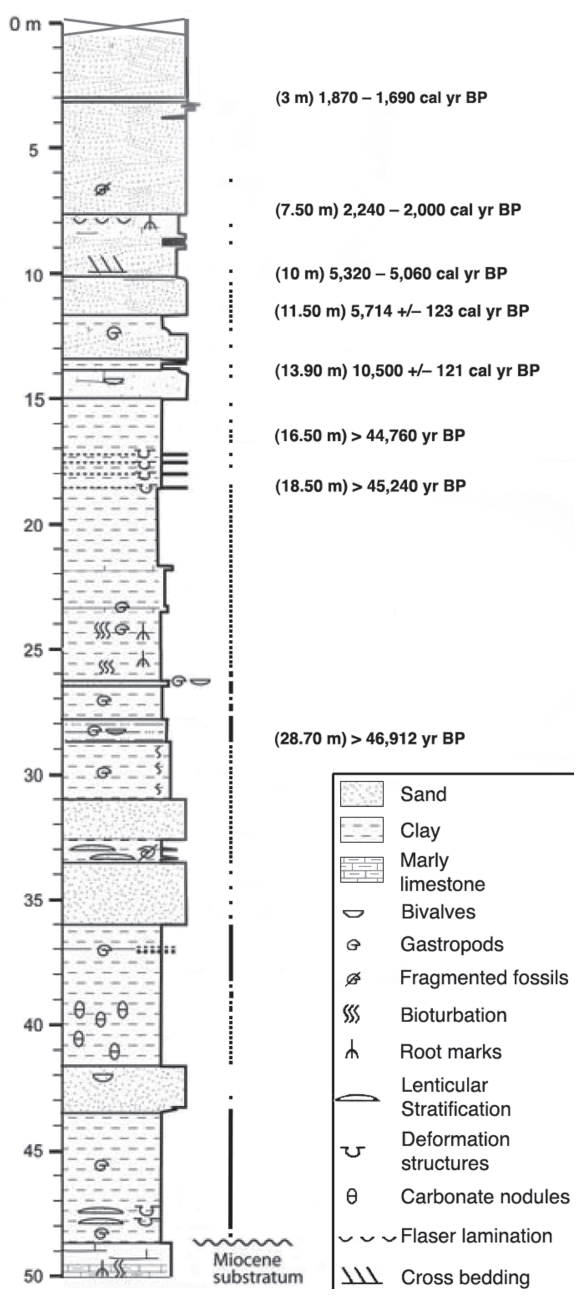

Figure 2. Stratigraphic column of the Xeraco borehole. Dots represent sampling points and continuous lines represent sections with sampling every $10 \mathrm{~cm}$. Modified from García-Blázquez et al. (2008).

\subsection{Age depth model}

An age depth model has been developed using eight available radiocarbon dates provided by García-Blázquez et al. (2008), and their location of the Bølling-Allerød warm period at $16.30 \mathrm{~m}$, which mostly encompasses the upper half of the series (Fig. 2). In order to complete the information on the lower half of the core, and basing on the interpretation of García-Blázquez et al. (2008), levels $43.50 \mathrm{~m}$ and $37 \mathrm{~m}$ have been tentatively dated as $71000 \mathrm{yr}$ $\mathrm{BP}$ and $57000 \mathrm{yr} \mathrm{BP}$, assuming they are close to the MIS 5-MIS 4 and MIS 4-MIS 3 transitions (Marine Isotopic Stage transition dates are taken from the Lisiecki \& Raymo [2005] LR04 Benthic Stack). The slope of the 43.50-37 m interval of the age depth model was employed to estimate sample dates before $71000 \mathrm{yr}$ BP.

Subsequently this age depth model has been used to plot the variation of foraminiferal diversity versus the 
estimated age throughout the core. Two selected diversity indices: Margalef richness and Shannon-Wiener diversity, with similar numerical ranges, have been employed.

\section{RESULTS}

The core reached a total depth of $60 \mathrm{~m}$, but only the upper $50 \mathrm{~m}$ containing the Quaternary materials are shown in Figure 2. Its base consists of Miocene white marly limestones with root remains and bioturbation. Unconformably on these materials, the first Quaternary sediments can be found at $49 \mathrm{~m}$ depth. Along the core, successive environments with more or less marine influence are defined by their benthic foraminiferal assemblages and facies. Materials mostly consist of lagoonal silts and clays intercalated with increasingly predominant washover and eolian sand layers containing molluscs, ostracods and benthic foraminifers. A more detailed description is given in García-Blázquez et al. (2008).

A total of 205 samples, recovered from the upper 49 $\mathrm{m}$ of Quaternary sediments have been studied. The whole number of picked foraminiferal tests is 178066 , that is, an average of 862 specimens per sample (Supplementary Data, Table 1: http://sepaleontologia.es/informacionsuplementaria/) which covers the occurrence of even the least abundant species in the different environments represented along the borehole. A total of 127 taxa have been identified. Five of them correspond to lagoonal species strongly related to restricted, continentally influenced environments; 15 species are associated with transitional zones with marine influence and the rest are clearly marine taxa (Murray, 1973, 1991).

In the first group the species are Ammonia tepida (Cushman, 1926), Cribroelphidium excavatum (Terquem, 1875), Deuterammina dublinensis Brönnimann \& Whittaker, 1983, Haynesina germanica (Ehrenberg, 1840), Trichohyalus aguayoi (Bermúdez, 1935). The most abundant species in this group is $C$. excavatum (Fig. 3), with a relative abundance that averages $14.69 \%$, followed by $H$. germanica with an average relative abundance of $10.71 \%$. Both species show a wide range of variation $(0.25-63.27 \%$ for $C$. excavatum and $0-49.15 \%$ for $H$. germanica), particularly in the lower half of the series, where they reach their maximum frequencies $(C$. excavatum at $37.30 \mathrm{~m}$ and $H$. germanica at $36.10 \mathrm{~m}$ ). The rest of species are very rare although they are clear indicators of marginal and restricted environments.

The species in the transitional group are as follows: Ammonia beccarii (Linné, 1758), Aubignyna perlucida (Heron-Allen \& Earland, 1913), Bolivina earlandi Parr, 1950, Bolivina striatula (Cushman, 1922), Buliminella elegantissima (d'Orbigny, 1839), Cornuspira involvens (Reuss, 1850), Cribroelphidium incertum Williamson,

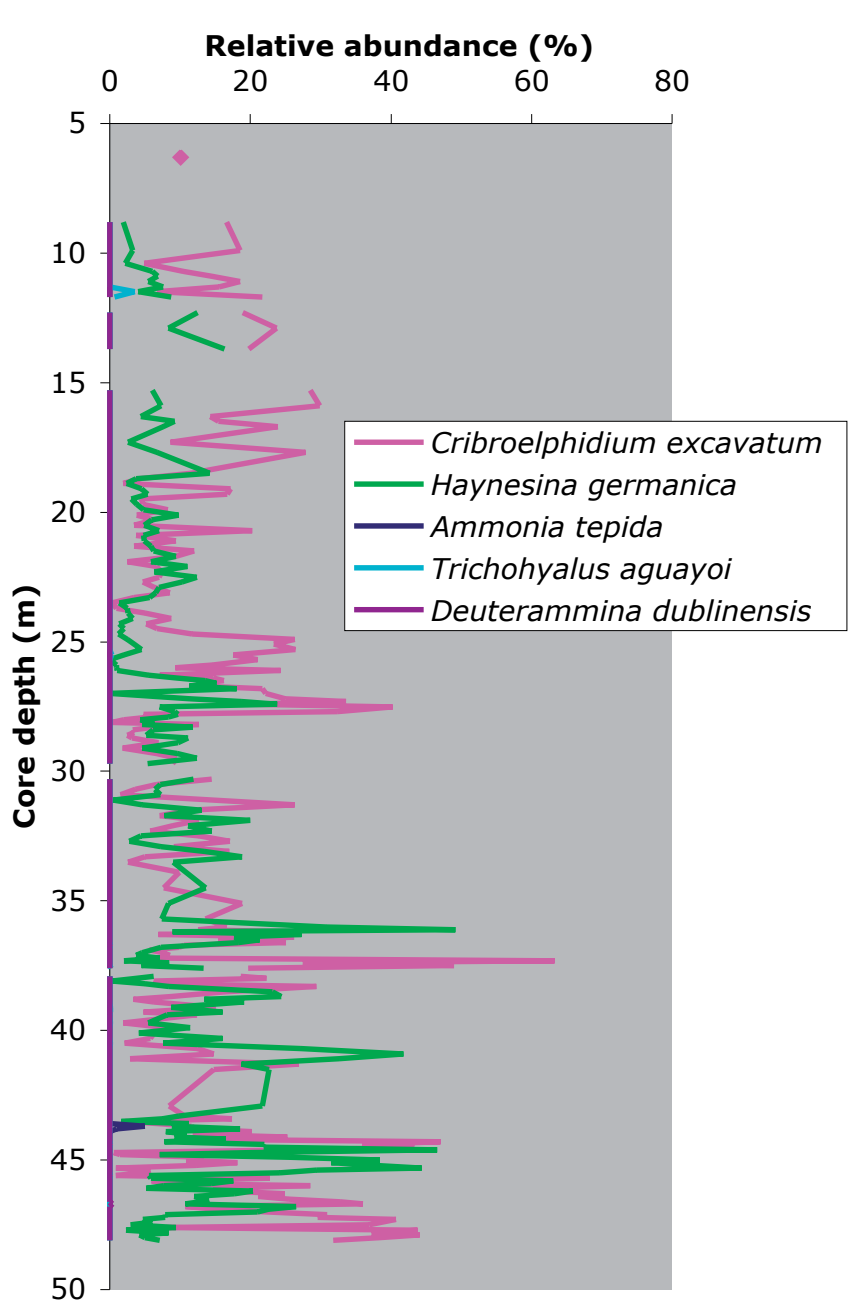

Figure 3. Relative abundance (percentage) variation of the lagoonal species along the Xeraco borehole.

1858, Elphidium clavatum Cushman, 1930, Elphidium granosum (d'Orbigny, 1826), Elphidium williamsoni Haynes, 1973, Haynesina depressula (Walker \& Jacob, 1798), Haynesina sp., Quinqueloculina seminula (Linné, 1758), Pseudolachlanella eburnea (d'Orbigny, 1839), and Triloculina oblonga (Montagu, 1803). Among this group, the most abundant species is by far A. beccarii (Fig. 4), with an average relative abundance of $62.82 \%$ and an extremely wide variation range: $0.58-98.38 \%$, particularly in the first $15 \mathrm{~m}$ of the core, whereas it becomes more constantly dominant in the central portion of the series (e.g. between 32.30 and $18.70 \mathrm{~m}$ ). It occurs in large numbers both in the most marine influenced levels (e.g. at 46.80 $\mathrm{m}, 37.20 \mathrm{~m}$ or $36.90 \mathrm{~m}$ ) and in the transitional ones (e.g. at $47.70 \mathrm{~m}, 40.70 \mathrm{~m}$ or $28.10 \mathrm{~m}$ ). The rest of species are much less represented. Cribroelphidium incertum (average relative abundance: $0.93 \%$ ) is only abundant in the central portion of the core where it reaches $32.97 \%$ at $28.10 \mathrm{~m}$. Haynesina depressula (averaging $0.48 \%$ ) attains maximum values at specific levels in the first half of the series 


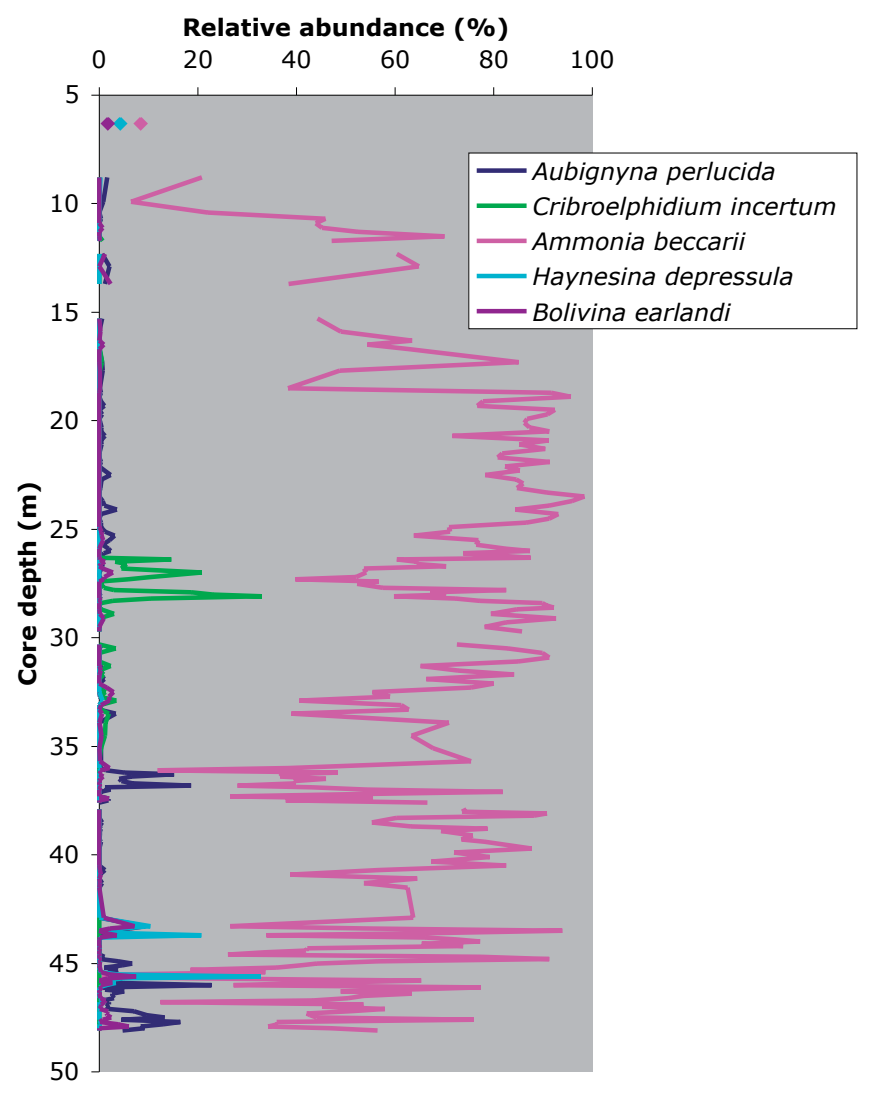

Figure 4. Relative abundance (percentage) variation of the five most abundant transitional species along the Xeraco borehole.

(e.g. $32.81 \%$ at $45.60 \mathrm{~m}$ ), like $A$. perlucida (average: $1.61 \%$; maximum: $22.73 \%$ at $46 \mathrm{~m}$ ) or $B$. earlandi (average: $0.44 \%$; maximum: $7.48 \%$ at $45.60 \mathrm{~m}$ ).

The rest of species, listed in Table 1 (Supplementary Data), are strictly marine. Many are miliolid taxa, among which the most abundant species are Miliolinella subrotunda (Montagu, 1803), which averages $0.86 \%$ and varies between 0 and $33.69 \%$, Pseudotriloculina rotunda (Schlumberger, 1893), with a relative abundance ranging from 0 to $32.54 \%$ and averaging $1.20 \%$, and Triloculina schreiberiana d'Orbigny, 1839 (average: 0.63\%; range: 0-24.16\%). In addition the Rosalina group, which mainly includes Rosalina globularis (d'Orbigny, 1826) and Rosalina mediterranensis d'Orbigny, 1826, together with Rosalina anglica (Cushman, 1931), Rosalina anomala Terquem, 1875, Rosalina bradyi (Cushman, 1915) and Rosalina williamsoni (Chapman \& Parr, 1932), is dominant in both the base (where it attains $21 \%$ ) and the uppermost levels of the core, which show a strong marine influence (Fig. 5). Nevertheless, due to its absence in many samples, the whole group shows a low average relative abundance $(0.78 \%)$ throughout the core. These species live fixed to leaves of marine phanerogams or to littoral rocky substrates. Most milioids are also associated to marine phanerogam meadows (Murray, 1973, 1991,

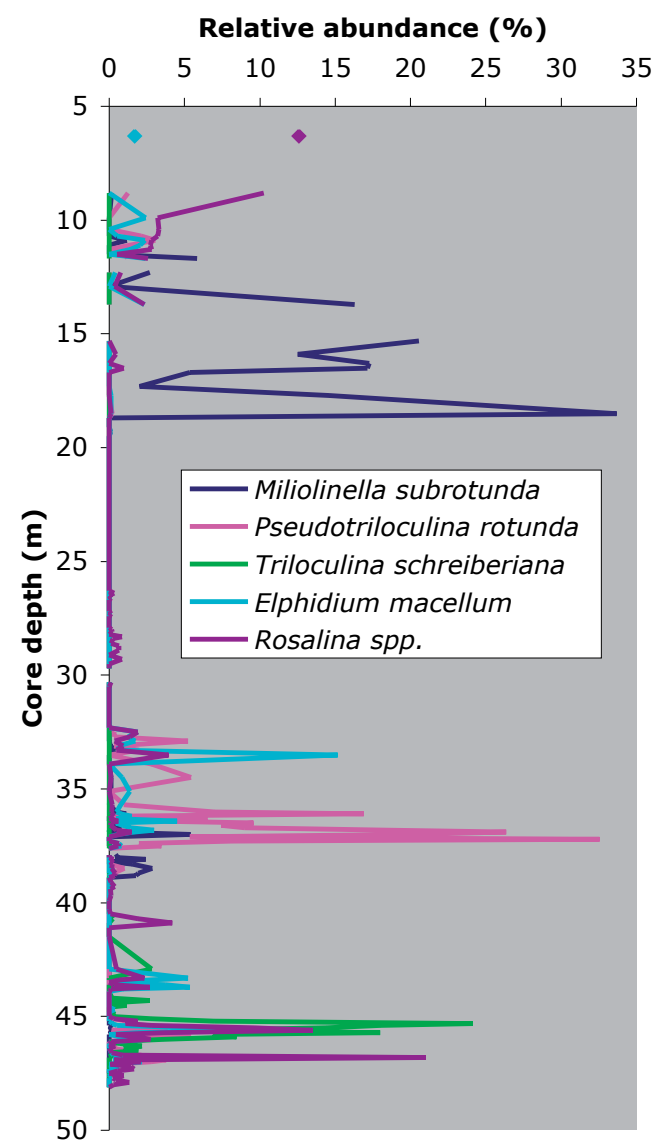

Figure 5. Relative abundance (percentage) variation of the five most abundant marine taxa along the Xeraco borehole.

2006). The tests of these benthic marine taxa were included in the sediments deposited in the Xeraco area when the shoreline was closer.

The percentage of these strictly marine species is represented in Figure 6. As it can be observed, in the lowermost part of the borehole from 48.10 to $32.50 \mathrm{~m}$ depth, the assemblages of benthic foraminifera are subject to strong oscillations, with peak abundances of marine taxa at $46.80 \mathrm{~m} \mathrm{(45.55 \% ),} 45.60 \mathrm{~m} \mathrm{(48.92 \% ),} 36.90 \mathrm{~m}$ $(42.39 \%)$ and $33.50 \mathrm{~m}(41.75 \%)$, and their total absence at $45 \mathrm{~m}, 44.80 \mathrm{~m}, 44.60 \mathrm{~m}, 44.40 \mathrm{~m}, 43.90 \mathrm{~m}, 41.10-41.50$ $\mathrm{m}$ or $39.90-40.30 \mathrm{~m}$. Their average relative abundance throughout the whole interval is $8.82 \%$.

From $32.30 \mathrm{~m}$ to $18.70 \mathrm{~m}$ depth there is a nearly total lack of marine species (the maximum relative abundance is $1.72 \%$ at $31.50 \mathrm{~m}$ ), but at $18.50 \mathrm{~m}$ and above marine taxa significantly increase again and reach the maximal frequencies along the borehole $(70.97 \%$ at $9.90 \mathrm{~m}$ and $73.11 \%$ at $6.30 \mathrm{~m}$ depth).

The undoubtedly dominant species in Xeraco, $A$. beccarii, is very common in transitional and littoral environments and its coiling direction has been interpreted as the consequence of environmental changes (Longinelli \& Tongiorgi, 1964; see also Guillem \& Usera, 2004). 
In Xeraco, sinistral-coiled individuals of $A$. beccarii are dominant throughout the borehole (Fig. 7). Dextral coiled specimens represent $30-40 \%$ of the $A$. beccarii tests in most of the samples and rarely depart significantly from this range. They reach minimal percentages at $44.70 \mathrm{~m}$, $36.90 \mathrm{~m}, 28.30 \mathrm{~m}$ (when they show the minimal value in the borehole: $18.93 \%$ ) and $25.30 \mathrm{~m}$ depth, whereas they peak at $47.90 \mathrm{~m}, 37 \mathrm{~m}, 33.30 \mathrm{~m}, 31.10 \mathrm{~m}, 17.70 \mathrm{~m}$, $15.90 \mathrm{~m}$ (maximum value: $48.43 \%$ ) and $11.30 \mathrm{~m}$. Coiling direction variations do not seem to be linked here to environmental changes, since maximal and minimal values occur both in strictly lagoonal and in transitional or marine influenced moments. Similar percentage values were found by Usera et al. (1990c) in a Quaternary core in the locality of Pego (Alicante, Spain).

Some of the foraminiferal species recovered in the Xeraco borehole are shown in Figures 8 and 9.

\subsection{Diversity}

The Fisher $\alpha$ and the Margalef richness indices show an almost identical pattern throughout the core and are then described together.

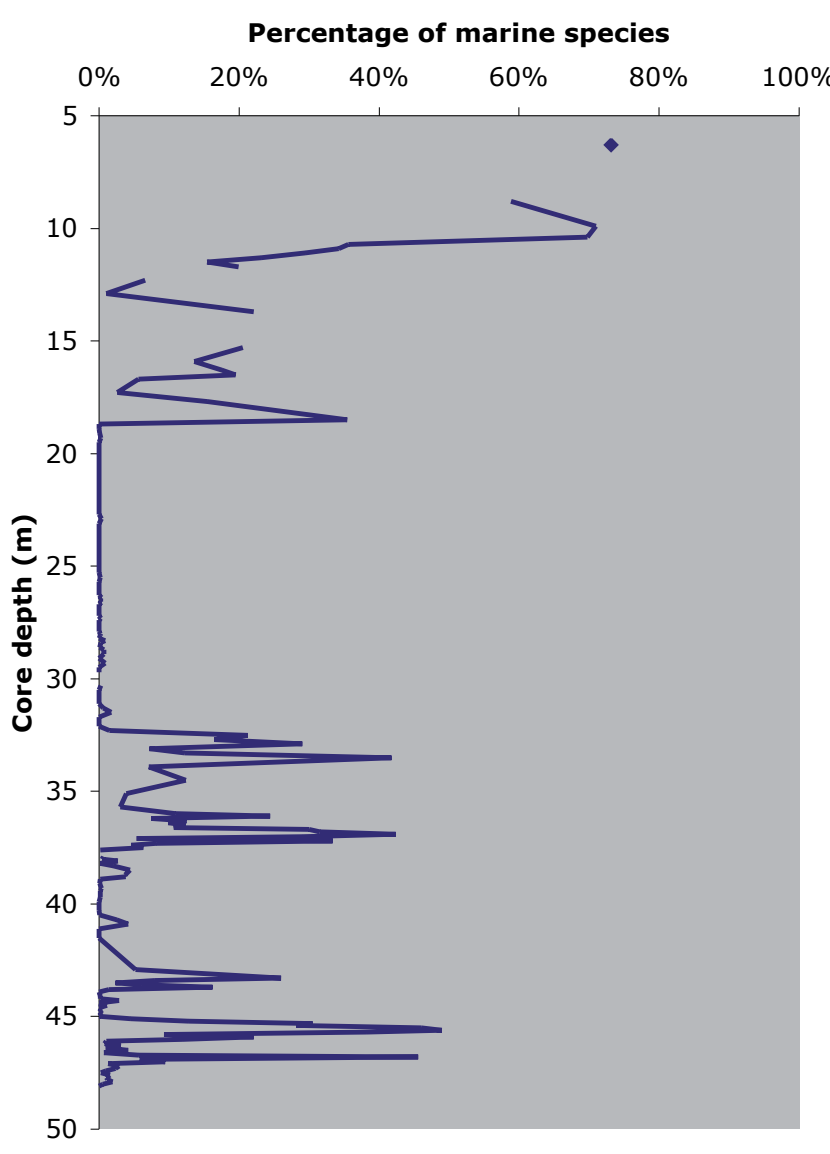

Figure 6. Relative abundance (percentage) variation of foraminiferal tests belonging to strictly marine taxa along the Xeraco borehole.

\subsubsection{Fisher $\alpha$ and Margalef richness}

In the lower part of the core and up to $32.10 \mathrm{~m}$ depth, strong oscillations can be observed (Fig. 10), with peaks (e.g., at 46.80 m, Fisher: 5.24 and Margalef: 3.84 or at $45.60 \mathrm{~m}$, Fisher: 7.47, Margalef: 5.35) alternating with rather low values (e.g. at 43.90 m, Fisher: 0.37, Margalef: $0.28)$. After an interval with relatively low diversity between $41.50 \mathrm{~m}$ (Fisher: 0.48, Margalef: 0.39) and 37.60 m (Fisher: 0.76, Margalef: 0.64), generally higher values are recorded (mainly between $36.90 \mathrm{~m}$ and $32.70 \mathrm{~m}$; e.g., at $33.50 \mathrm{~m}$, Fisher: 5.90 , Margalef: 4.18 or at $32.70 \mathrm{~m}$, Fisher: 5.96, Margalef: 4.17). Diversity then drops and remains low from $32.10 \mathrm{~m}$ to $18.70 \mathrm{~m}$. Fisher $\alpha$ never exceeds 1.5, whereas Margalef richness is always below 1.25 , with an average for this interval of respectively 0.71 and 0.58 . Both indices attain their minimum values at $24.50 \mathrm{~m}$ (Fisher: 0.35, Margalef: 0.26). In the upper part of the series strong fluctuations occur together with an increasing trend and the maximum values of the core are attained at $6.30 \mathrm{~m}$ core depth (Margalef: 7.11 and Fisher: 16.6, not shown in Fig. 10).

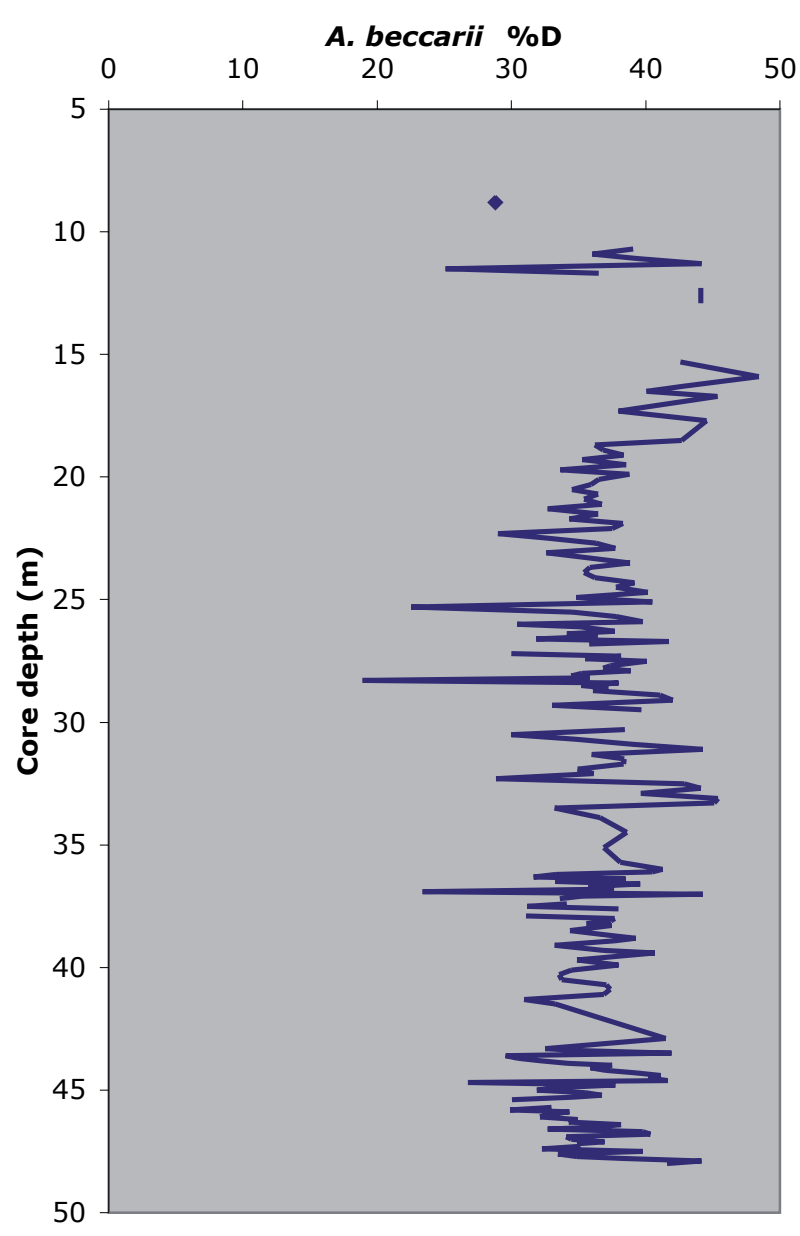

Figure 7. Percentage variation of dextral-coiled tests in Ammonia beccarii along the Xeraco borehole. 


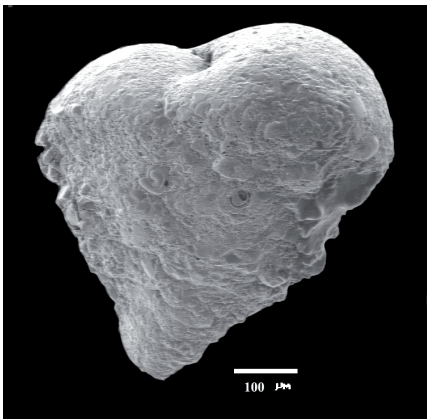

a

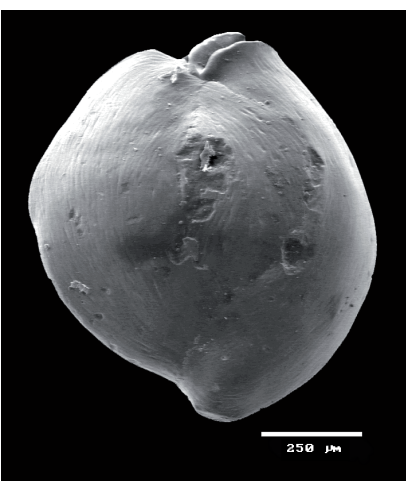

d

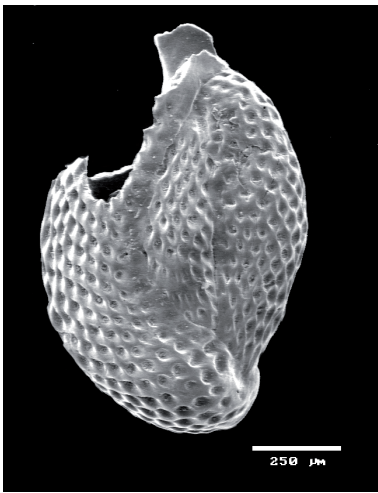

$\mathbf{g}$

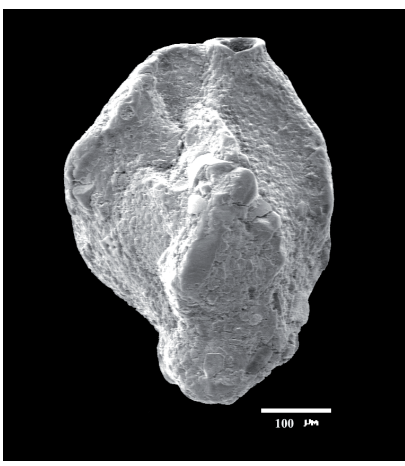

j

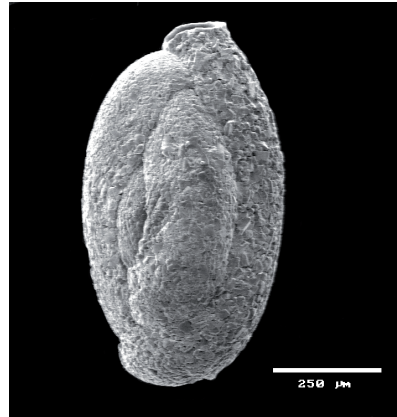

b

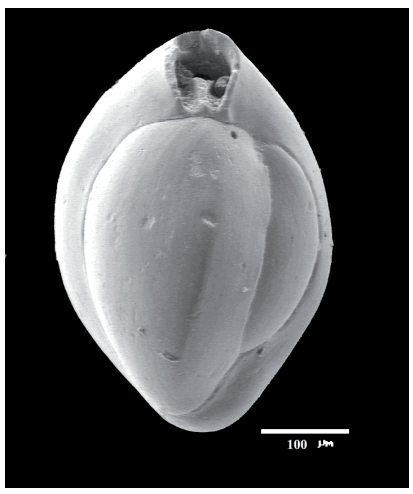

e

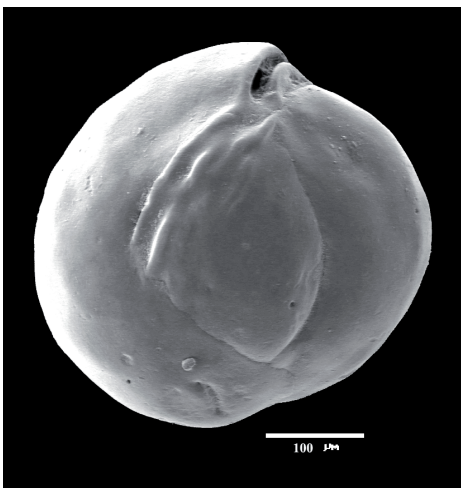

$\mathbf{h}$

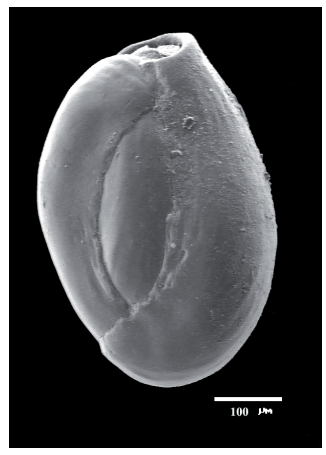

k

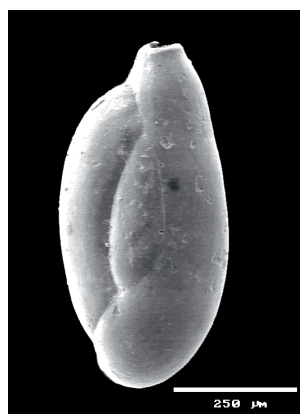

c

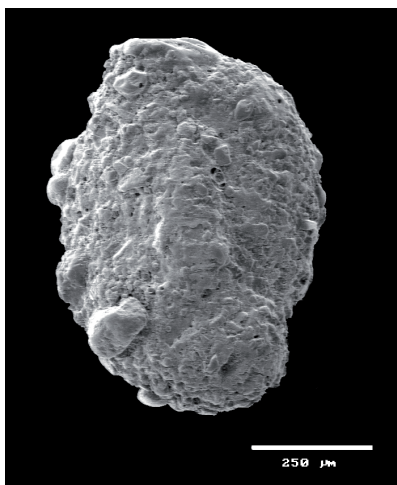

f

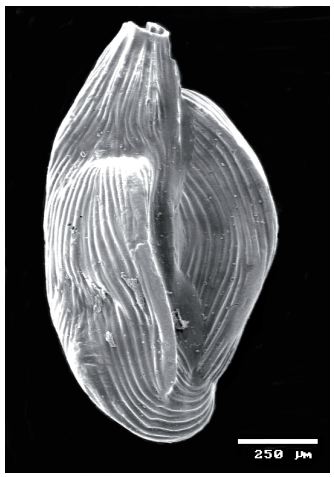

i

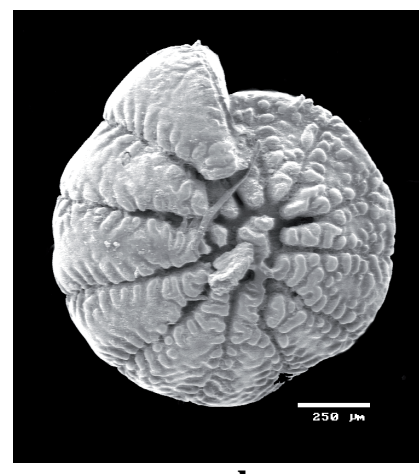

I

Figure 8. a) Textularia pseudogramen Cushman \& Parr, 1937. b) Siphonaperta aspera (d'Orbigny, 1826). c) Adelosina longirostris (d'Orbigny, 1846). d) Quinqueloculina lamarckiana d'Orbigny, 1839. e) Triloculina trigonula (Lamarck, 1804). f) Quinqueloculina agglutinans d'Orbigny, 1839. g) Quinqueloculina cf. reticulata Karrer, 1862. h) Miliolinella circularis (Bornemann, 1855). i) Adelosina colomi (Le Calvez \& Le Calvez, 1958). j) Quinqueloculina berthelotiana d'Orbigny, 1839. k) Quinqueloculina seminula Linné, 1758. I) Ammonia beccarii (Linné, 1758). 


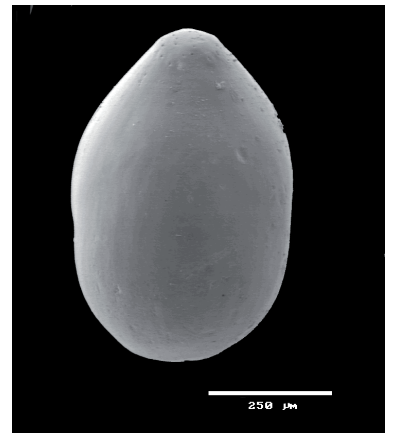

a

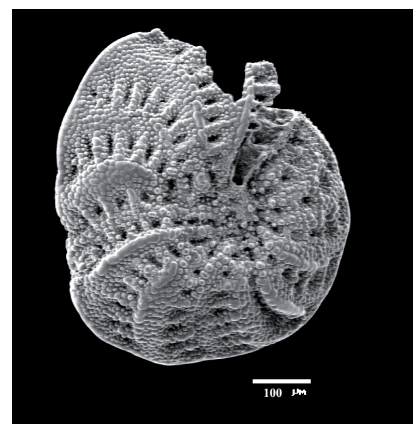

d

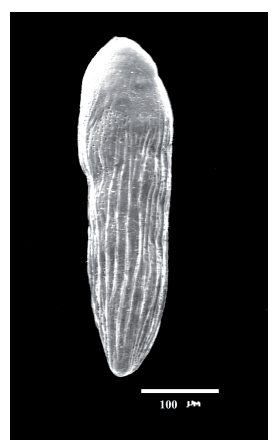

g

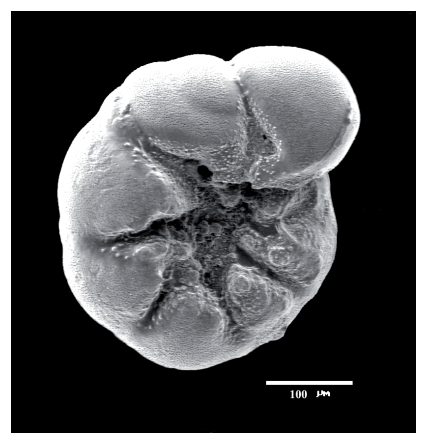

b

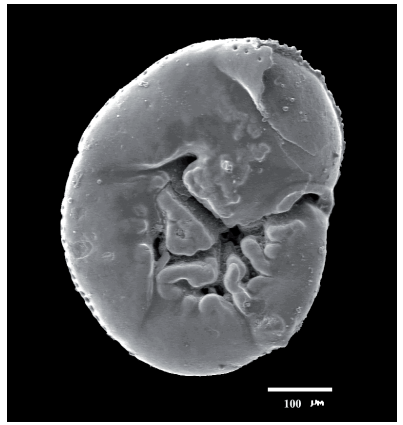

e

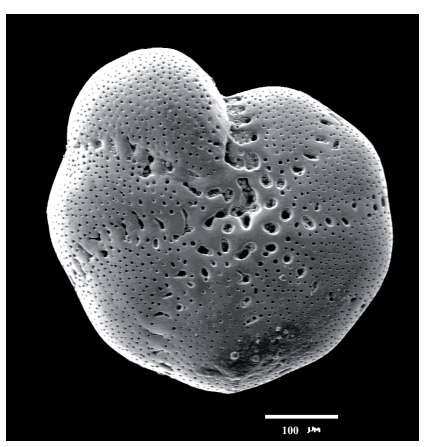

h

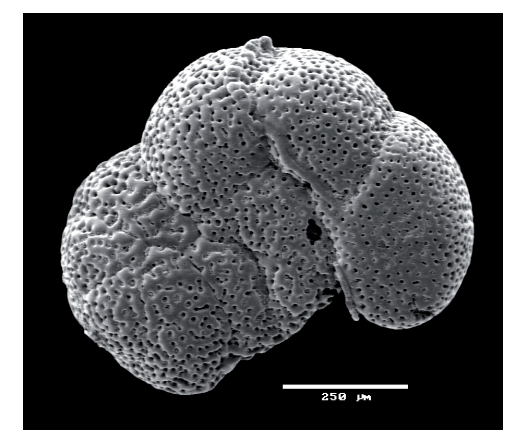

c

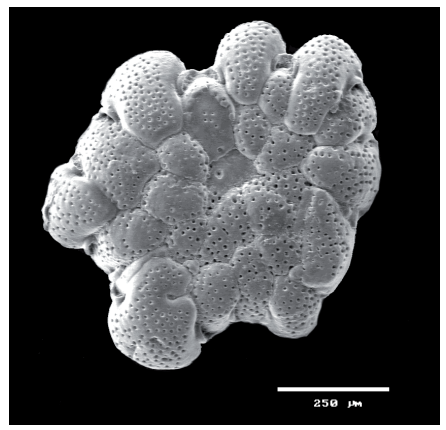

f

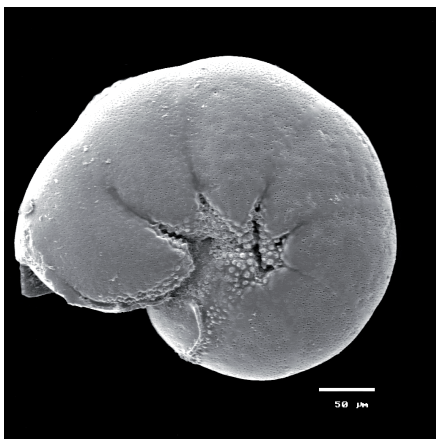

i

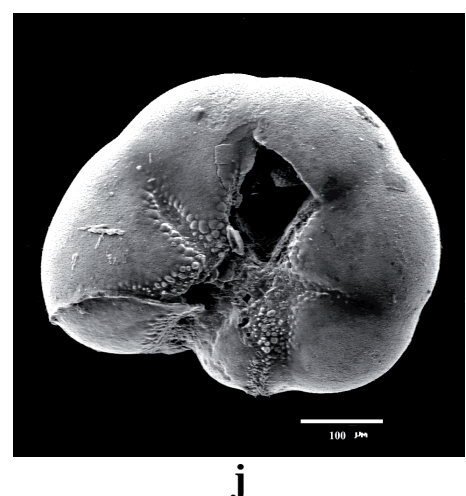

Figure 9. a) Globulina gibba (Deshayes, 1830). b) Ammonia tepida (Cushman, 1926). c) Lobatula lobatula (Walker \& Jacob, 1798). d) Elphidium macellum (Fichtel \& Moll, 1798). e) Rosalina globularis d'Orbigny, 1826. f) Planorbulina mediterranensis d'Orbigny, 1826. g) Bolivina striatula Cushman, 1922. h) Cribroelphidium excavatum (Terquem, 1875). i) Haynesina germanica (Ehrenberg, 1840). j) Aubignyna perlucida (Heron-Allen \& Earland, 1913). 


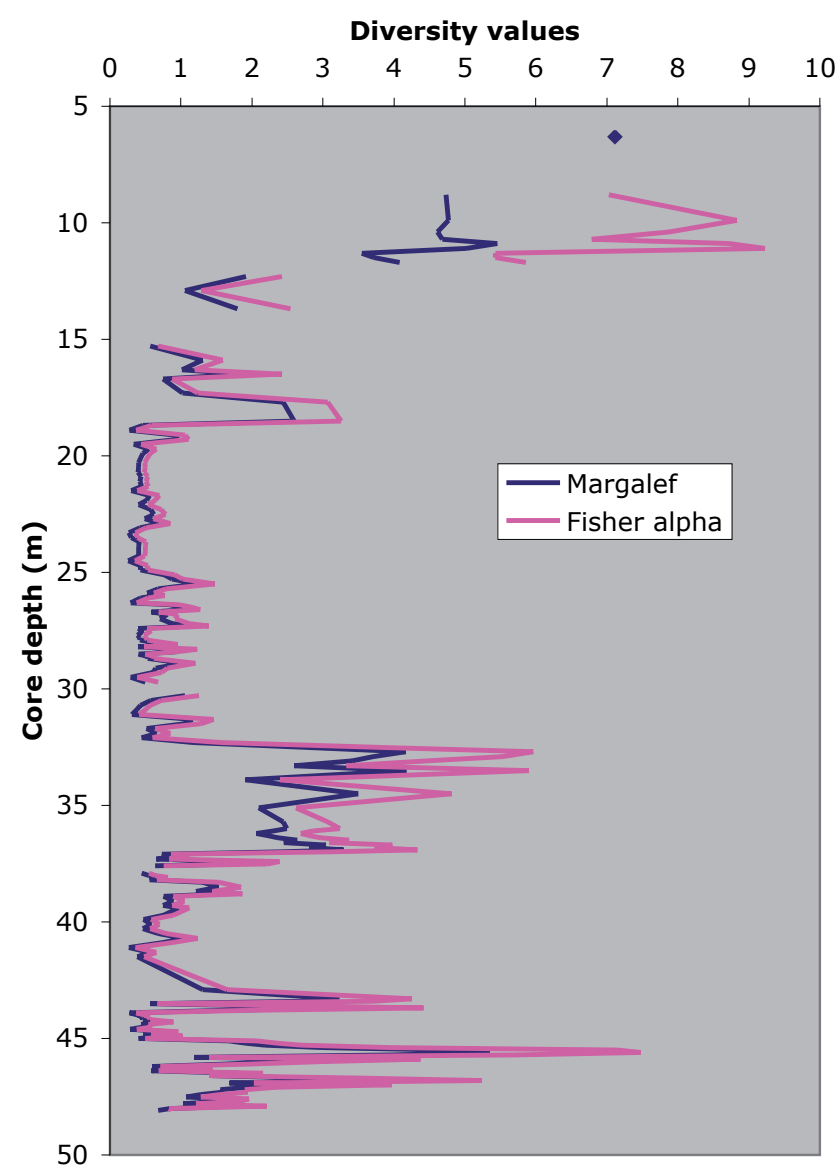

Figure 10. Fisher $\alpha$ and Margalef richness variation along the Xeraco borehole. The Fisher $\alpha$ value at $6,30 \mathrm{~m}$ depth $(16,6)$ has not been included in the figure.

\subsubsection{Shannon-Wiener $H^{\prime}$}

This index (Fig. 11) also shows high values in the lower part of the core from $46.80 \mathrm{~m} \mathrm{(2.23)} \mathrm{to} 32.90 \mathrm{~m} \mathrm{(2.17),}$ but strongly oscillates, with minimal values at $44.80 \mathrm{~m}$ (0.34), at $43.50 \mathrm{~m}(0.30)$ or at $38.10 \mathrm{~m}(0.38)$ and peaks at $45.50 \mathrm{~m}$ (2.52), $43.30 \mathrm{~m}$ (2.37) or $33.50 \mathrm{~m}$ (2.28). Above $32.10 \mathrm{~m}$ depth the index shows both lower values and less variation (from 0.09 at $23.50 \mathrm{~m}$ to 1.32 at $27.30 \mathrm{~m}$ ) but then it rises again and reaches its maximum towards the top of the borehole (2.73 at $9.90 \mathrm{~m}$ or 3.17 at $6.30 \mathrm{~m}$ ).

\subsubsection{Pielou J'or Equitability}

Since this index is based on the Shannon index it follows the same general trend (Fig. 11). Minimal values are recorded at $43.50 \mathrm{~m}(0.19)$ or at $23.50 \mathrm{~m}(0.08)$, where $A$. beccarii is overwhelmingly dominant and occurs with only two other species. On the contrary, maximal values are noticed in moments of strong marine influence, at $44.60 \mathrm{~m}$ $(0.97)$ or in the uppermost samples, at $9.90 \mathrm{~m}(0.86)$ or $6.30 \mathrm{~m}(0.89)$.

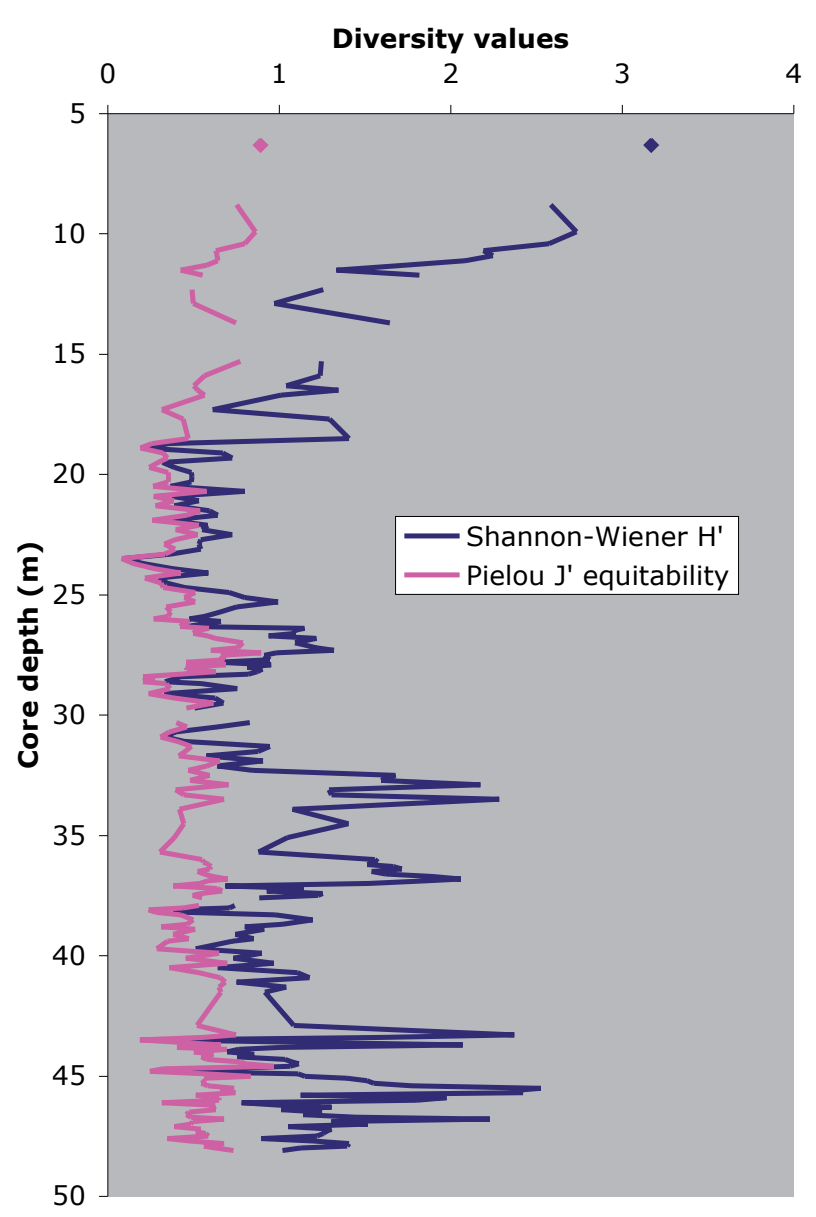

Figure 11. Shannon-Wiener H' diversity and Pielou J' equitability values along the Xeraco borehole.

\subsubsection{Species richness}

Finally, we can evaluate the variation of the species richness (number of species) along the core (Fig. 12). Considering that higher species diversity is associated to stable environments and that it decreases in more isolated and unstable conditions (Margalef, 1958; Murray, 1973), the figure shows the varying influence of the marine realm. The number of mesolittoral and infralittoral species increases and reaches peak values of 36 (at $45.60 \mathrm{~m}$ ), 35 (at $6.30 \mathrm{~m}$ ), 34 (at $10.90 \mathrm{~m}$ ) or 29 species (at $33.50 \mathrm{~m}$ ), when the shoreline was presumably closer to the Xeraco area. Contrasting with them, several samples along the borehole show only 3 species, the lowermost one at 48.35 $\mathrm{m}$, and particularly between $32.10 \mathrm{~m}$ and $18.70 \mathrm{~m}$. The minimal value throughout the core $(2$ species at $8.10 \mathrm{~m})$ is not significant since only 2 tests were recovered.

\subsection{Radiometric datings}

García-Blazquez et al. (2008) and Usera et al. (2012) originally provided the radiocarbon datings $\left({ }^{14} \mathrm{C}\right)$ shown 
in Figure 2. The oldest ones at $28.70 \mathrm{~m}(>46912 \mathrm{yr} \mathrm{BP})$,

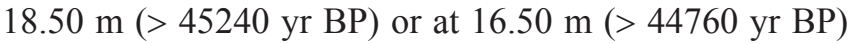
correspond to the Upper Pleistocene whereas the one at $13.90 \mathrm{~m}$ depth (10500 $\pm 121 \mathrm{cal} \mathrm{yr} \mathrm{BP})$ and above (5714 \pm 123 cal BP; 5320-5060 cal yr BP; 2240-2000 cal yr BP or 1870-1690 cal yr BP) are clearly Holocene in age.

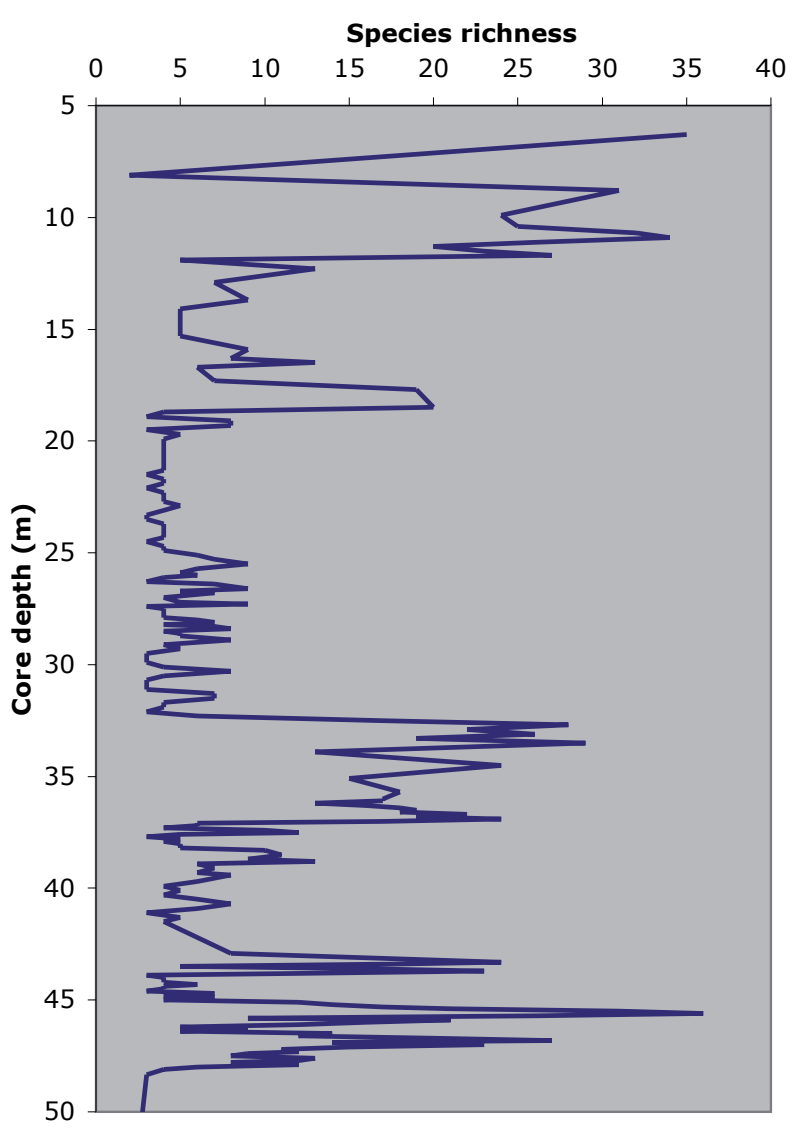

Figure 12. Species richness (number of foraminiferal species) variation along the Xeraco borehole.

\subsection{Age model}

The age depth model (Fig. 13) strongly suggests there is a probable hiatus or nearly non-deposition period between $16.50 \mathrm{~m}$ (dated as $44760 \mathrm{yr} \mathrm{BP}$ ) and $16.30 \mathrm{~m}$ core depth, where García-Blázquez et al. (2008) located the BøllingAllerød (dated as $13000-15000 \mathrm{yr}$ BP, $14000 \mathrm{yr}$ BP in this model), which would encompass the uppermost part of the MIS 3 and most of the MIS 2 stage, including the Last Glacial Maximum, LGM). The intervals below and above this hiatus show notably similar average sedimentation rates: $\sim 1.03 \mathrm{~m} / \mathrm{kyr}$ for the $43.50 \mathrm{~m}-16.50 \mathrm{~m}$ section and $\sim 1.09 \mathrm{~m} / \mathrm{kyr}$ for the $16.30 \mathrm{~m}-3 \mathrm{~m}$ interval.

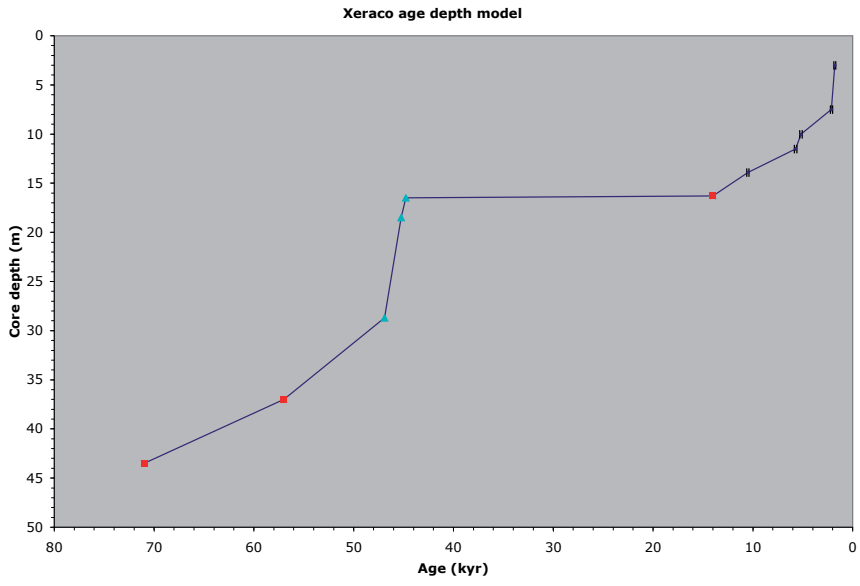

Figure 13. Age depth model for the Xeraco core based on data obtained from García-Blázquez et al. (2008). Black points with error bars: calibrated radiocarbon; blue triangles: minimum non-calibrated ages; red squares: Bølling-Allerød and assumed limits MIS-5-MIS-4 and MIS-4-MIS-3.

\subsection{Diversity versus estimated age}

The temporal variation of diversity along the core is represented in Figure 14. The Margalef richness and the Shannon-Wiener diversity indices show a very similar pattern, with strong oscillations in the lower part of the series (enlarged in Fig. 14b). Remarkable peaks at (estimated) 78108 yr BP (Margalef: 3.84; Shannon: 2.23), 75523 yr BP (Margalef: 5.35; Shannon: 2.35) or 71431 yr BP (Margalef: 3.30; Shannon: 2.07) and $70569 \mathrm{yr}$ BP (Margalef: 3.23; Shannon: 2.37) alternate with low values, e.g. at 77246 yr BP (Margalef: 0.59; Shannon: 1.01), 71862 yr BP (Margalef: 0.29; Shannon: 0.72) or 71000 yr BP (Margalef: 0.56; Shannon: 0.30). This is followed by a relatively long period between approximately $68000 \mathrm{yr}$ BP and $59000 \mathrm{yr}$ BP of low diversity (with the Margalef index only exceeding 1.5 in two samples). High values are recorded between $57000 \mathrm{yr} \mathrm{BP}$ and $51000 \mathrm{yr}$ $\mathrm{BP}$ (a maximum is attained at $52746 \mathrm{yr} \mathrm{BP}$, Margalef: 4.18; Shannon: 2.28) and afterwards again an interval of relatively low diversity around $46000-45000 \mathrm{yr}$ BP (e.g. Margalef: 0.30; Shannon: 0.09 at 46057 BP). After a last increase in diversity (Margalef: 2,59; Shannon: 1.41 at $45240 \mathrm{yr} \mathrm{BP}$ ), the supposed non-deposition period is displayed as a data gap between 44000 and $14000 \mathrm{yr}$ BP. Above this, the uppermost part of the Pleistocene and the Holocene record is visibly fragmentary, but reflects a rapid increase of diversity around 6000-5000 yr BP. 


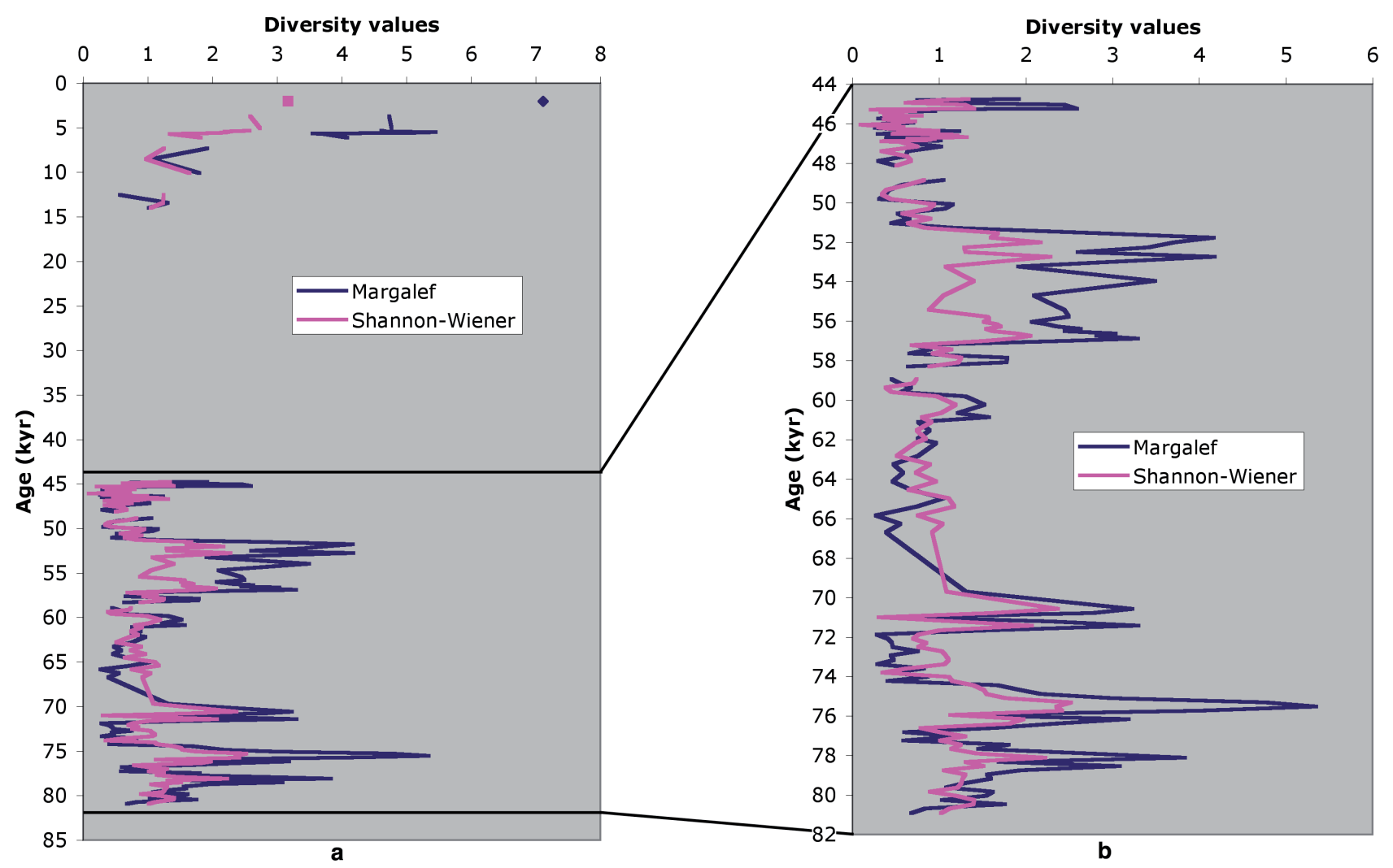

Figure 14. a) Margalef richness and Shannon-Wiener H' diversity variation versus estimated age along the whole Xeraco core. b) Enlargement of the previous plot showing the lower part of the core.

\section{DISCUSSION}

The identified species along the core seem to point to two moments of maximal marine influence, determined by the abundance of the strictly marine species group together with a high number of species at both the lower and the uppermost (above $18.50 \mathrm{~m}$ ) parts of the sequence. Nevertheless, from $48.35 \mathrm{~m}$ to $32.10 \mathrm{~m}$, these episodes of close proximity of the shoreline are frequently punctuated by intervals in which there is a total lack of open marine species (e.g. at $45 \mathrm{~m}, 44.20 \mathrm{~m}$ or at $40.50-39.10$ $\mathrm{m})$, possibly representing short episodes of a lagoonal environment with only a slight drainage connection to the sea. The assemblage of species indicative of transitional environments is well defined in the middle of the borehole, where A. beccarii, H. germanica or C. incertum are more abundant. These levels with scarce occurrence of marine species might be interpreted as a phase with a more distant shoreline and with the brackish lagoon still somewhat influenced by the sea, as it is indicated by the presence of A. perlucida and B. elegantissima.

The diversity and richness indices seem to confirm this interpretation since they reach their maximal values at the base and the uppermost part of the sequence and show high variability in the lower part up to $32.10 \mathrm{~m}$ depth, which supports the environmental instability in this Upper Pleistocene interval. The upper levels up to $18.90 \mathrm{~m}$ depth, with low diversity and equitability, probably reflect a more stable lagoon environment still subject to restricted conditions that favour the occurrence of a reduced number of species very well adapted to annual climatic fluctuations in the basin. Both richness and diversity increase again towards the top of the series with a new phase of strong marine influence during which the lagoon finally dries off and is replaced by eolian dunes and beach sediments.

\subsection{Diversity versus estimated age interpretation}

It should be kept in mind that, except for the radiocarbon ages in the upper part of the core, the rest of age assignments are only estimations. Due to the uncertainties of the age depth model, any inference based on it must be taken with caution.

Nevertheless, it can be deduced that the strong diversity changes of the lower part of the core reflect millennial scale climatic oscillations (probably Dansgaard-Oeschger stadials and interstadials) with cold periods, during which the Xeraco lagoon was isolated from the sea, alternating with warm periods, in which the lagoon was closer to the 
coastline and more prone to marine influence, via washover events that would transport marine foraminiferal tests, or even temporal breaks of the bar, thus transforming the lagoon in an enclosed bay. Several abrupt cooling and warming changes have been recorded in the interval 80000-70000 yr BP (during the MIS-5a substage) in the western Mediterranean, such as stadials AS-21 and AS20 or interstadials AI-20 and AI-19 (Martrat et al., 2004), which might correspond to the wide oscillations observed in the lower part of the core. The prolonged interval of low diversity that follows, between the estimated ages $68000 \mathrm{yr}$ BP and $59000 \mathrm{yr}$ BP, approximately matches the relatively cold MIS-4, in which the Heinrich 6 (HE-6) event has been shown to have had a discernible effect on both planktonic and benthic foraminiferal assemblages in the Alborán Sea (Pérez-Folgado et al., 2003, 2004; PérezMartín et al., 2006). The subsequent interval of prolonged high diversity between the estimated ages $57000 \mathrm{yr}$ BP and $51000 \mathrm{yr}$ BP indicates a stable relatively warm period that possibly corresponds to the Interstadials AI-14 and AI-13, as recorded in several Mediteranean studies (e.g. Martrat et al., 2004; Sprovieri et al., 2012; Incarbona et al., 2013). The next low diversity interval represented by a relatively long core section (from $32.10 \mathrm{~m}$ to $18.70 \mathrm{~m}$ depth; Figs 10-12) suggests a distant shoreline, between approximately $50000 \mathrm{yr} \mathrm{BP}$ and $45000 \mathrm{yr} \mathrm{BP}$, and particularly around 46000 yr BP, which is coincident with the Heinrich 5 (HE-5) cold spell, whose effects have been recorded in the western Mediterranean by several authors (PérezFolgado et al., 2003; Martrat et al., 2004; Sierro et al., 2005; Frigola et al., 2008).

The Holocene sequence is incomplete (Fig. 14) but the diversity increase shows the growing marine influence associated to the development of the Flandrian transgression around 6000-5000 yr BP until the establishment of beach facies and eolian dunes in the uppermost part of the series.

\subsection{Comparison with other areas}

Several studies have treated the Quaternary evolution of foraminifera from coastal restricted environments in the western Mediterranean area, but many are limited to the Holocene. In the Iberian Peninsula, this is the case of the Ebro delta (Cearreta et al., 2016), the Vilanova i La Geltrú peat bog (Calzada, 1970), the Peníscola marsh (Usera et al., 2006), the Torreblanca lagoon (Colom, 1959; Collado \& Robles, 1983; Usera et al., 1996a), the Albufera of València (Robles et al., 1985; Carmona et al., 2016) or the Albufereta of Alacant (Blázquez \& Ferrer, 2003; Ferrer et al., 2005). Although Upper Pleistocene sediments have been preserved in the Albufera of Alcúdia (Mallorca), the studied foraminiferal assemblages are Holocene in age (Viñals \& Mateu, 1999).
Other authors have reported the occurrence of Upper Pleistocene coastal lagoon environments with foraminiferal assemblages. In a $90 \mathrm{~m}$ core drilled in Tuscany (Italy) Carboni et al. (2010) reported sediments with foraminiferal assemblages typical of a restricted lagoon (dominated by Ammonia parkinsoniana (d'Orbigny, 1839) together with Cribroelphidium poeyanum (d'Orbigny, 1839), $H$. depressula and $H$. germanica) subject to environmental variability and affected by a transgressive episode, tentatively ascribed by the authors to a slight sea-level rise during MIS-3, which perhaps might be related to the interval of high diversity recorded in Xeraco between $36.90 \mathrm{~m}$ and $32.70 \mathrm{~m}$ depth (Figs 10-12) and estimated as $57-51$ kyr (Fig. 14).

In the Pego Quaternary lagoon (about $20 \mathrm{~km} \mathrm{SE} \mathrm{from}$ Xeraco) four different cores have been studied (Dupré et al., 1988; Mateu, 1989; Viñals et al. 1989; García-Forner, 1997; Torres et al., 2014). Two transgressive episodes, tentatively dated as MIS-5, have been recognized, with marine sediments (including foraminifera tests) transported into the lagoon, alternating with phases characterised by an enclosed lagoon environment with freshwater or brackish conditions, in which case foraminifers like A. beccarii, H. germanica or C. excavatum are predominant. After the establishment of a peat bog, dated as early Holocene, the Flandrian transgression (around $5000 \mathrm{yr} \mathrm{BP}$ ) is also recorded in Pego. The lack of more chronologic precisions for the Pleistocene part of the series precludes further comparisons with the Xeraco core.

In the Xàbia marsh (located about $40 \mathrm{~km} \mathrm{SE}$ from Xeraco) up to five cores were studied by Fumanal et al. (1993), some of which reach the Middle Pleistocene (MIS-9), and show alternating littoral and lagoonal facies with their characteristic foraminiferal fauna together with continental facies. The Upper Pleistocene transgressive phase (MIS-5) is recorded and characterised by marine stenohaline foraminifera (including planktonic forms, not recorded in Xeraco), after which stages MIS-4, MIS-3 and MIS-2 are poorly differentiated and are followed by Holocene lagoonal deposits with brackish foraminifera and increasing marine influence (see also Viñals et al., 1993; García-Forner, 1997).

Middle and Upper Pleistocene transgressive and regressive movements of the shoreline are also preserved in the ancient coastal lagoon of Elx (up to MIS-12). Blázquez (2005) and Blázquez \& Usera (2010) recorded different MIS-5 substages in three studied cores (starting with a brackish lagoon phase corresponding to MIS-5d in core Pinet). If the age ascriptions of the lower part of the Xeraco core were correct, its observed wide fluctuations of diversity, indicating the close proximity of the shoreline, would correspond to the shoreface bed deposited in the Salinas core (Units IV and V) in Elx and attributed by Blázquez \& Usera (2010) to substage MIS-5a. Above this transgressive episode, no sedimentary record of 
stages MIS-4, 3 or 2 has been detected in Elx. A brackish lagoon subject to an increasing marine influence and dated as Holocene is finally replaced, as in Xeraco, by beach (shoreface/foreshore) deposits.

\section{CONCLUSIONS}

The study of the foraminiferal assemblages and the autoecological characteristics of some of the occurring species suggest that this area of the Mediterranean coast was first subject to warm climate conditions, with high sea level and a shoreline close to the borehole location, and that the conditions of a lagoon subjected to a strong marine influence and frequent washover events, with some millennial scale environmental fluctuations, persisted up to the $32.10 \mathrm{~m}$ depth. Afterwards the assemblage data show a sudden drop in diversity and a nearly total absence of littoral species. These conditions continued up to the 18.70 $\mathrm{m}$ depth and are interpreted as a lagoon environment in colder/glacial climatic conditions with low sea level and a more distant shoreline. Finally the diversity increase and the reappearance of littoral foraminifera in the upper part of the sequence indicate a new sea level rise which, according to the radiocarbon datings, can be attributed to the Flandrian transgression, already in a new interglacial warm phase, in which the Xeraco lagoon is finally replaced by beach deposits.

\section{ACKNOWLEDGEMENTS}

This is a contribution to projects HAR2016-77981 (Dirección General de Investigación Científica y Técnica, Subdirección General de Proyectos de Investigación; Ministerio de economía y competitividad) and IGCP639: Sea Level Changes from Minutes to Millennia. Special thanks are due to Alejandro Cearreta and an anonymous reviewer, whose comments have greatly improved the manuscript.

\section{REFERENCES}

[All historical references concerning original descriptions of the different taxa cited in the text or in Table 1 have been included as Supplementary Data in a separate list: (http://sepaleontologia.es/informacion-suplementaria/)].

Blázquez, A.M. 2005. Evolución Cuaternaria de l'Albufera d'Elx: Paleoambientes y Foraminíferos Fósiles. Memorias del Museo Paleontológico de Elche, Universidad de Alicante y MUPE. Alicante, 314 pp.

Blázquez, A.M. \& Ferrer, C. 2003. L'Albufereta d'Alacant: foraminíferos y evolución paleoambiental. Cuaternario y Geomorfología, 18, 55-72.

Blázquez, A.M \& Ferrer, C. 2012. Role of human actions on landscape changes since the Upper Holocene in the Bajo Segura Basin (SE Spain). Catena, 97, 31-40; doi: 10.1016/j.catena.2012.04.010.

Blázquez, A.M. \& Usera, J. 2010. Palaeoenvironments and Quaternary foraminifera in the coastal lagoon of Elx (Alicante, Spain). Quaternary International, 221, 68-90; doi: 10.1016/j.quaint.2009.06.033.

Calzada, S. 1970. Una turbera parálica postwürmiense en Vilanova y La Geltrú (Barcelona). Acta Geológica Hispánica, 5, 48-50.

Carboni, M.G., Bergamin, L., Di Bella, L., Esu, D., Pisegna Cerone, E., Antonioldi, F. \& Verrubbi, V. 2010. Palaeoenvironmental reconstruction of late Quaternary foraminifera and molluscs from the ENEA borehole (Versilian plain, Tuscany, Italy). Quaternary Research, 74, 265-276; doi: 10.1016/j.yqres.2010.07.006.

Carmona, P., Ruiz-Pérez, J.M., Blázquez, A.M., LópezBelzunce, M., Riera, S. \& Orengo, H. 2016. Environmental evolution and mid-late Holocene climate events in the Valencia lagoon (Mediterranean coast of Spain). The Holocene, 26, 1750-1765; doi: 10.1177/0959683616645940.

Cearreta, A., Benito, X., Ibáñez, C., Trobajo, R. \& Gosan, L. 2016. Holocene palaeoenvironmental evolution of the Ebro Delta (Western Mediterranean Sea): Evidence for an early construction based on the benthic foraminiferal record. The Holocene, 26, 1438-1456; doi: $10.1177 / 0959683616640048$.

Collado, M.A. \& Robles, F. 1983. Estudio de las asociaciones de moluscos de la turbera holocena de Torreblanca (Castellón). Mediterránea Serie Geológica, 1, 105-142.

Colom, G. 1959. Notas micropaleontológicas y ecológicas sobre algunas formaciones continentales españolas. Estudios Geológicos, 15, 93-106.

Dupré, M., Fumanal, M.P., Sanjaume, E., Santisteban, C., Usera, J. \& Viñals, M.J. 1988. Quaternary evolution of the Pego coastal lagoon (southern Valencia, Spain). Palaeogeography, Palaeoclimatology, Palaeoecology, 68, 291-299; doi: 10.1016/0031-0182(88)90046-6.

Fatela, F. \& Taborda, R. 2002. Confidence limits of species proportions in microfossil assemblages. Marine Micropaleontology, 45, 169-174; doi: 10.1016/S03778398(02)00021-X.

Ferrer, C. \& Blázquez, A.M. 2012. The evolution of the Albufereta lagoon (western Mediterranean): Climate cycles and sea level changes. Journal of Coastal Research, 28, 1617-1626; doi: 10.2112/JCOASTRES-D-11-00007.1.

Ferrer, C., Blázquez, A.M., Esquembre, M.A. \& Ortega, J.R. 2005. Reconstrucción paleoambiental de l'Albufereta d'Alacant durante el período ibero-romano (500 a.C.300 d.C.). In: Geomorfología Litoral i Quaternari (eds Sanjaume, E. \& Mateu, J.F.). Universitat de València, 137-150. 
Fisher, R.A., Corbet, A.S. \& Williams, C.B. 1943. The Relation between the number of species and the number of individuals in a random sample of an animal population. Journal of Animal Ecology, 12, 42-58.

Frigola, J., Moreno, A., Cacho, I., Canals, M., Sierro, F.J., Flores, J.A. \& Grimalt, J.O. 2008. Evidence of abrupt changes in Western Mediterranean Deep Water circulation during the last 50 kyr: A high-resolution marine record from the Balearic Sea. Quaternary International, 181, 88-104; doi: 10.1016/j.quaint.2007.06.016.

Fumanal, M.P. 1995. Los acantilados béticos valencianos. In: El Cuaternario del País Valenciano. Asociación Española para el Estudio del Cuaternario AEQUA, Universitat de València, 177-185.

Fumanal, M.P. \& Viñals, M.J. 1989. Los acantilados marinos de Moraira: su evolución pleistocena. Cuaternario y Geomorfología, 2, 23-32.

Fumanal, M.P., Viñals, M.J., Belluomini, G., Usera, J., Mateu, G. \& Dupré, M. 1991. Evolución cuaternaria de la Bahía de Xàbia: Registro sedimentario, rasgos biológicos y cronoestratigráficos. VIII Reunión Nacional sobre Cuaternario. Libro de excursiones, Valencia, 58-63.

Fumanal, M.P., Usera, J., Viñals, M.J., Mateu, G., Belluomini, G., Manfra, L. \& Proszynska-Bordas, H. 1993. Evolución cuaternaria de la Bahía de Xàbia (Alicante). In: Estudios sobre Cuaternario (eds Fumanal, M.P. \& Bernabeu, J.), Universitat de València, 17-26.

García-Blázquez, A.M., Goy, J.L., Zazo, C., Dabrio, C., Usera, J., Yll, R., Luque, L., Cabero, A. \& Bardaji, T. 2008. Cold-warm spells peaking the last $\sim 100 \mathrm{ka}$ at Xeraco lagoon (Western mediterranean, Spain). Fifth IGCP 495 Meeting, Quaternary Land-Ocean Interactions: Driving Mechanisms and Coastal Responses, Faro, 49-50.

García-Forner, A., 1997. Foraminiferos cuaternarios de las marjales de Oliva-Pego y Xàbia (Valencia-Alicante). Paleoecología y Evolución. PhD Thesis, Universidad de Valencia, $201 \mathrm{pp}$.

Goy, J.L., Zazo, C. \& Dabrio, C.J. 2003. A beach-ridge progradation complex reflecting periodical sea-level and climate variability during the Holocene (Gulf of Almería, Western Mediterranean). Geomorphology, 50, 251-268; doi: 10.1016/S0169-555X(02)00217-9.

Guillem, J. \& Usera, J. 2004. Estudio del sentido de enrollamiento en los foraminíferos bentónicos del marjal de Torreblanca (Castellón). Revista Española de Paleontología, 19, 61-72.

Hayek, L.C. \& Buzas, M.A. 1997. Surveying Natural Populations. Cambridge University Press, New York.

Incarbona, A., Sprovieri, M., Di Stefano, A., Di Stefano, E., Salvagio Manta, D., Pelosi, N., Ribera d'Alcalà, M., Sprovieri, R. \& Ziveri, P. 2013. Productivity modes in the Mediterranean Sea during Dansgaard-Oeschger (20,000-70,000 yr ago) oscillations. Palaeogeography, Palaeoclimatology, Palaeoecology, 392, 128-137; doi: 10.1016/j.palaeo.2013.09.023.

Lisiecki, L.E. \& Raymo, M.E. 2005. A Pliocene-Pleistocene stack of 57 globally distributed benthic $\delta^{18} \mathrm{O}$ records. Paleoceanography, 20, doi: 10.1029/2004PA001071.
Longinelli, A. \& Tongiorgi, E. 1964. Oxygen isotope composition of some right and left coiled Foraminifera. Science, 144, 1004-1005; doi: 10.1126/ science.144.3621.1004.

Magurran, A. 1989. Diversidad Ecológica y su Medición. Vedrá.

Marco-Barba, J., Holmes, J.A., Mesquita-Joanes, F. \& Miracle, M.R. 2013. The influence of climate and sea-level change on the Holocene evolution of a Mediterranean coastal lagoon: Evidence from ostracod palaeoecology and geochemistry. Geobios, 46, 409-421; doi: 10.1016/j. geobios.2013.05.003.

Margalef, D.R. 1958. Information theory in ecology. General Systematics, 3, 36-71; doi: 10.1016/S00978485(01)00073-0.

Martrat, B., Grimalt, J.O., López-Martínez, C., Cacho, I., Sierro, F.J., Flores, J.A., Zahn, R., Canals, M., Curtis, J.H. \& Hodell, D.A. 2004. Abrupt Temperature Changes in the Western Mediterranean over the Past 250,000 Years. Science, 306, 1762-1765; doi: 10.1126/science.1101706.

Mateu, G. 1989. Sondeo de l'Albufera de Pego (Valencia): micropaleontología y biofacies. Cuadernos de Geografia, $45,1-9$.

Murray, J.W. 1973. Distribution and Ecology of Living Benthic Foraminifera. Heinemann, London.

Murray, J.W. 1991. Ecology and Palaeoecology of Benthic Foraminifera. Longman, Harlow.

Murray, J.W. 2006. Ecology and Applications of Benthic Foraminifera. Cambridge University Press, New York.

Patterson, R.T. \& Fishbein, A. 1989. Re-examination of the statistical methods used to determine the number of point counts needed for micropaleontological quantitative research. Journal of Paleontology, 63, 245-248.

Pérez-Folgado, M., Sierro, F.J., Flores, J.A., Cacho, I., Grimalt, J.O., Zahn, R. \& Shackleton, N. 2003. Western Mediterranean planktonic foraminifera events and millennial climatic variability during the last $70 \mathrm{kyr}$. Marine Micropaleontology, 48, 49-70; doi: 10.1016/ S0377-8398(02)00160-3.

Pérez-Folgado, M., Sierro, F.J., Flores, J.A., Grimalt, J.O. \& Zahn, R. 2004. Paleoclimatic variations in foraminifer assemblages from the Alboran Sea (Western Mediterranean) during the last $150 \mathrm{ka}$ in ODP Site 977. Marine Geology, 212, 113-131; doi: 10.1016/j. margeo.2004.08.002.

Pérez-Martín, R., Sierro, F.J. \& Flores, J.A. 2006. Variaciones en las faunas de foraminíferos bentónicos del Mar de Alborán durante el evento Heinrich 6. Geogaceta, 40, 223-226.

Pielou, E.C. 1969. An Introduction to Mathematical Ecology. Wiley-Interscience John Wiley \& Sons.

Robles, F., Collado, M.A. \& Borredá, V. 1985. Variaciones de la fauna de moluscos en la Albufera de Valencia: implicaciones paleogeográficas. Geomorfología Litoral y Cuaternario. 123-133.

Rosselló, V.M. 1995. L'Albufera de València (Sèrie il.lustrada 11). Publicacions de l'Abadia de Montserrat, Barcelona. 
Sanjaume, E. 1985. Las costas valencianas. sedimentología y morfología. PhD. Thesis. Sección de Geografía, Universidad de Valencia. 505 pp.

Sanjaume, E. \& Carmona, P. 1995. L'Albufera de València: rasgos geomorfológicos y evolución cuaternaria. In: $E l$ Cuaternario del País Valenciano, Asociación Española para el Estudio del Cuaternario, Universitat de València, 155-162.

Santisteban, C., Marco-Barba, J. \& Miracle M.R. 2009. La evolución Holocena de la Albufera de Valencia. Geogaceta, 46, 99-102.

Shannon, C.E. \& Weaver, W. 1949. The Mathematical Theory of Communication. University Illinois Press, Urbana, IL.

Sierro, F.J., Hodell, D.A., Curtis, J.H., Flores, J.A., Reguera, I., Colmenero-Hidalgo, E., Bárcena, M.A., Grimalt, J.O., Cacho, I., Frigola, J. \& Canals, M. 2005. Impact of iceberg melting on Mediterranean thermohaline circulation during Heinrich events. Paleoceanography, 20, doi: 10.1029/2004PA001051.

Sprovieri, M., Di Stefano, E., Incarbona, A., Salvagio Manta, D., Pelosi, N., Ribera d'Alcalà, M. \& Sprovieri, R. 2012. Centennial- to millennial-scale climate oscillations in the Central-Eastern Mediterranean Sea between 20,000 and 70,000 years ago: evidence from a highresolution geochemical and micropaleontological record. Quaternary Science Reviews, 46, 126-135; doi: 10.1016/j. quascirev.2012.05.005.

Torres, T., Ortiz, J.E. \& Martín-Sánchez, D. 2014. The long Pleistocene record from the Pego-Oliva marshland (Alicante-Valencia, Spain). Geological Society of London, Special Publications, 388, 429-452; doi: 10.1144/SP388.2.

Usera, J. \& Mateu, G. 1995. Foraminíferos cuaternarios en el País Valenciano. In: El Cuaternario del País Valenciano. Asociación Española para el Estudio del Cuaternario, Universitat de València, 245-250.

Usera, J., Domingo, C. \& García-Forner, A. 1990a. Dinámica poblacional de foraminíferos en un sondeo de la albufera cuaternaria de Jávea (Alicante). VI Jornadas de Paleontología, Resúmenes de Comunicaciones, Granada, p. 60.

Usera, J., Faura, M. \& Arco, Y. 1990b. Foraminíferos cuaternarios de las fases de colmatación de la Albufera de Valencia. VI Jornadas de Paleontología, Resúmenes de Comunicaciones, Granada, p. 61.

Usera, J., De Renzi, M., García-Forner, A. \& Alberola, C. 1990c. Retención o pérdida de información paleobiológica a través de los procesos tafonómicos: Una discusión basada en las proporciones de dos tafones de Ammonia beccarii (Linné) (Foraminiferida). Comunicaciones de la Reunión de Tafonomía y Fosilización (coord. Fernández López, S.). Madrid, 369-378.
Usera, J., Alberola, C., García-Forner, A. \& Guillem, J. 1996a. Proceso de colonización y evolución en la composición de las asociaciones de foraminíferos fósiles en la turbera cuaternaria de Torreblanca (Castellón). Coloquios de Paleontología, 48, 147-159.

Usera, J., López Buendía, A. \& Alberola, C. 1996 b. Foraminíferos cuaternarios de la turbera de Benicasim (Castellón). XII Bienal de la Real Sociedad Española de Historia Natural, Madrid 1996. p. 200.

Usera, J., Blázquez, A., Guillem, J. \& Alberola, C. 2006. Evolución holocena de la marjal de Peñíscola (Castellón, España) deducida del estudio de sus foraminíferos fósiles. Revista Española de Micropaleontología, 38, 381-393.

Usera, J., Alberola, C., Guillem, J. \& Brito, J.M. 2012. Foraminíferos de la albufera cuaternaria de Xeraco (Valencia). XXVIII Jornadas de la Sociedad Española de Paleontología, Libro de resúmenes, Soller, 115-117.

Viñals, M.J. 1996. El marjal de Oliva-Pego (Valencia). Geomorfología y evolución de un humedal costero mediterráneo. PhD. Thesis, Universidad de Valencia, $352 \mathrm{pp}$.

Viñals, M.J. \& Fumanal, M.P. 1990. Modelo de evolución de una costa acantilada durante el Cuaternario: Cap de la Nau-Punta de Moraira. In: El Cuaternario de España y Portugal. II Reunión del Cuaternario Ibérico. (eds Aleixandre, T. \& Pérez González, A.). Instituto Tecnológico Geominero. Madrid, 25-32.

Viñals, M.J. \& Fumanal, M.P. 1991. El Cuaternario reciente de la rada de Moraira: el complejo relicto de restingaalbufera. VIII Reunión Nacional sobre Cuaternario. Libro de Excursiones. AEQUA-SIP-Universitat de València, 55-58.

Viñals, M.J. \& Mateu, G. 1999. Reconstrucción ambiental de la secuencia holocena en S'Albufera d'Alcúdia (Mallorca, España). In: Geomorfologia Litoral $i$ Quaternari, Memorial Maria Pilar Fumanal. Universitat de València, 447-456.

Viñals, M.J., Mateu, G., Fumanal, M.P., Usera, J. \& Favero, V. 1989. Aportación al conocimiento de las facies lagunares y litorales de la marjal de Oliva-Pego. Cuaternario y Geomorfología, 3, 93-104.

Viñals, M.J., Belluomini, G., Fumanal, M.P., Dupré, M., Usera, J., Mestres, J. \& Manfra, L. 1993. Rasgos paleoambientales holocenos en la bahía de Xàbia (Alicante). In: Estudios sobre Cuaternario (eds Fumanal, M.P. \& Bernabeu, J.). Universitat de València, 107-114.

Zazo, C., Dabrio, C.J., Goy, J.L., Lario, J., Cabero, A., Silva, P.G., Bardají,T., Mercier, N., Borja, F. \& Roquero, E. 2008. The coastal archives of the last $15 \mathrm{ka}$ in the Atlantic-Mediterranean Spanish linkage area: Sea level and climate changes. Quaternary International, 181, 7287; doi: 10.1016/j.quaint.2007.05.021. 
